\title{
UJI DAYA HAMBAT EKSTRAK RIMPANG SEGAR KUNYIT PUTIH (Curcuma zedoaria, Berg) TERHADAP PERTUMBUHAN KUMAN GRAM POSITIF DAN GRAM NEGATIF IN VITRO
}

\author{
Elizabeth Bahar \\ Bagian Mikrobiologi Fakultas kedokteran Universitas Andalas
}

\begin{abstract}
Known as white turmeric crop of crop medicines anti cancer where this crop rimpang contain immeasurable chemical vitamin in the reality can pursue many of cancer cell. Though unegual germ cell its structure with cancer cell but process many of is same cell perform a replicace. Have been done/conducted by research of test sensitivity of extract of rimpang fresh of white turmeric in so many concentration $100 \%, 75 \%, 50 \%$ and $25 \%$ to growth of germ of Staphylococcus aureus, Salmonella typhii, Pseudomonas aeruginosa dan Escherichia coli of in vitro to know its sensitivity. Research of experiment by using factorial pattern in complete random device (RAL) with 5 restating. From result of research obtained by extract of rimpang fresh white tumeric in so many concentration not pursue growth of germ of Staphylococcus aureus, Salmonella typhi, Pseudomonas aeruginosa dan Escherichia coli. Its conclusion of extract of rimpang fresh of white turmeric non influence growth of Gram positive and Gram negative bacteria.
\end{abstract}

Keywords: extract, fresh rimpang, white turmeric, germ

\section{DAFTAR PUSTAKA}

1. C. Syukur, Temu Putih, Tanaman Obat Anti Kanker, Penerbit Swadaya Bogor, 2004, 3.

2. C. K. Putu dan S. Widayat, Peran Jamu Obata Herbal Terstandar dan Fitofarmaka Sebagai Modus Terapi Di Indonesia, Jurnal Kunyit Putih, Yogyakarta, 2, (2007).

3. A. Solihkah, Kunir Putih Melawan Kanker Dengan Immunomodulator,
Jurnal Media Penelitian dan Pengembangan Kesehatan, 16, 2006.

4. Pusat Data Dan Informasi perhimpunan Rumah Sakit Seluruh Indonesia, Temu Putih, Jakarta, 2006, $25-26$.

5. E. Jawetz, J. L. Melnick, E.A Adelberg, Staphylococcus dan Enterobacteriacea Dalam Mikrobiologi Klinik Kedokteran, 20, 2006, 211, 238, 249.

6. L. Buntaran, Strategi Baru Dalam Pengobatan Infeksi Bacterial, Konas IV, Petri, Bali, 2000, 3. 
